\title{
ANÁLISE DA MODELAGEM DA INFORMAÇÃO DA CONSTRUÇÃO (BIM) EM PROCESSOS DE PROJETOS INDUSTRIAIS ${ }^{1}$
}

\author{
ANALYSIS OF BUILDING INFORMATION MODELING IN INDUSTRIAL \\ DESIGN PROCESSES \\ Ezequiel Rosa Dias \\ Departamento de Engenharia de Materiais e Construção, Escola de Engenharia (UFMG) \\ ezequiel.rosadias@gmail.com \\ Eduardo Marques Arantes \\ Departamento de Engenharia de Materiais e Construção, Escola de Engenharia (UFMG) \\ arantes@demc.ufmg.br
}

\begin{abstract}
Resumo
Pesquisas BIM no Brasil são ainda incipientes, principalmente no âmbito industrial. Buscou-se, neste trabalho, analisar o emprego do BIM em projetos industriais por um grupo de empresas de Belo Horizonte. Apresentam-se resultados finais da pesquisa de Dias (2015), realizada por meio de entrevistas não estruturadas e análises de documentações. As empresas utilizam a modelagem 3D para visualização e verificação de interferências, ao passo que buscam interoperabilidade entre ferramentas BIM e de modelagem industrial, mescla que pode induzir o uso de novas tecnologias pelo setor AEC. Cada disciplina desenvolve um modelo 3D-parametrizado. Contudo, o modelo integrado não carrega características paramétricas suficientes para o emprego de simulações de todo o empreendimento. Adota-se uma ferramenta própria para gestão de materiais e promoção de interoperabilidade entre ferramentas de modelagem. A necessidade de mão-de-obra especializada e custos elevados para desenvolvimento de padrões próprios de interoperabilidade, contudo, pode conferir exclusividade às empresas que os utilizam. Tal fato pode induzir projetistas com menos recursos a adotarem padrões de interoperabilidade de desenvolvedores de softwares, podendo se tornar prisioneiros dos mesmos. Nesse sentido, a participação das universidades se torna relevante na promoção de parcerias com a iniciativa privada, visando desenvolver padrões públicos para disseminação do conhecimento na área.
\end{abstract}

Palavras-chave: BIM. Modelagem Paramétrica Industrial. Interoperabilidade.

\begin{abstract}
BIM research in Brazil is still incipient, mainly in the industrial sector. This paper aimed to analyze the use of BIM in industrial designs by a group of companies from Belo Horizonte. Here we present the final results of the research of Dias (2015), conducted through non-structured interviews and documentation analysis. Companies use 3D modeling for visualization and interference checking, while seeking interoperability between BIM and industrial design tools, a blend that can induce the use of new technologies by the AEC industry. Each discipline develops a 3D parameterized model. Nevertheless, the integrated model does not carry enough parametric features to simulate the whole enterprise. Companies adopt their own tool to material management and to promote interoperability between modeling tools. The need for skilled labor and high costs for developing proprietary standards, however, confer exclusivity to companies that use them. That can lead designers with fewer resources to adopt interoperability standards from software developers, risking to become their hostages. In this sense, the participation of universities becomes relevant in promoting partnerships with the private sector with the aim of developing open standards for the dissemination of knowledge in the area.
\end{abstract}

Keywords: Building Information Modeling. Industrial Parametric Modeling. Interoperability.

${ }^{1}$ DIAS, E.; ARANTES, E. Análise da Modelagem da Informação da Construção (BIM) em processos de projetos industriais. In: ENCONTRO BRASILEIRO DE TECNOLOGIA DE INFORMAÇÃO E COMUNICAÇÃO NA CONSTRUÇÃO, 7., 2015, Recife. Anais... Porto Alegre: ANTAC, 2015. 